\title{
Path Analysis Of Work Intervening Variables
}

\author{
Pristiyono, Ade Parlaungan Nasution, Siti Lam'ah Nasution, Ronal Watrianthos, Yudi Triyanto
}

\begin{abstract}
The relationship between employee performance and job satisfaction lies in the achievement of a goal. The existence of organizational support signifies the implementation of leadership has run according to the needs of the organization. Job satisfaction has a direct influence on the dependent variable Organization Citizenship Behavior. This makes the Organization Citizenship Behavior a new concept in performance systems because high employee performance creates a high quality of work. Tujuan penelitian ini adalah mengetahui hubungan langsung dan tidak langsung antara leadership dan Organization Citizenship Behavior terhadap kinerja karyawan melalui variabel kepuasan kerja. The purpose of this study was to determine the direct and indirect relationship between leadership and Organization Citizenship Behavior on employee performance through job satisfaction variables. The path analysis technique is used to test the relationship between variables with the help of SPSS software. The primary data in this study were the results of the questionnaire related to the variables studied as many as 113 respondents from employees of PT. FIF Rantauprapat. The test results show leadership has no significant direct relationship to employee performance, whereas Organization Citizenship Behavior has a significant direct relationship to job satisfaction through employee performance variables because it has a $p$-value $(0,000)$ smaller than the sig level $(0,1)$ and has t-value $(5,714)$ is greater than t-hit $(1,96)$.
\end{abstract}

Index Terms- Employee performance, Job satisfaction, Organization Citizenship Behavior, Path Analysis

\section{INTRODUCTION}

Achieving optimal performance satisfies work for individuals or groups[1]. Satisfaction arises from one's perception that the work output is relatively the same as the input. A person's perception based on experiences that have been experienced indirectly becomes a benchmark for the level of satisfaction or saturation[2].

The relationship between employee performance and job satisfaction lies in the achievement of a goal. The existence of organizational support signifies the implementation of leadership has run according to the needs of the organization[3]. This makes it easier for managers to engage employees in challenging jobs. Organizations are considered successful if employees do not only carry out their main tasks but also carry out extra tasks and actively participate in the organization.

Previous research[4] stated that the results of the path analysis test showed simultaneously the independent variables of transformational leadership. In another study also stated transformational leadership had a significant effect on team decision making and had a positive effect on employee performance[5][6].

Job satisfaction also has a direct influence on the dependent variable Organization Citizenship Behavior (OCB)[7]. This makes OCB a new concept in the performance system because high employee performance creates a high quality of work too. OCB can applicatively face various technical problems due to organizational changes[8].

The purpose of this study was to determine the direct and indirect relationship between leadership and OCB on employee performance through job satisfaction variables. It will also be known the direct relationship of job satisfaction to job satisfaction.

\section{Methodology}

\subsection{Organizational Citizenship Behavior (OCB)}

Organizational Citizenship Behavior (OCB)[9] s a free individual behavior that is not directly recognized in the reward system. Free in the sense of behavior is not a requirement that must be carried out in certain roles or job descriptions[10]. OCB is an individual contribution that exceeds the role demands at work. This OCB involves several behaviors including helping people, volunteering for extra tasks, obeying the rules and procedures at work[11]. In simple terms, OCB can be in the form of employees who help solve other people's problems that are beyond the authority and responsibility of their work [11].

\subsection{Employee Performance}

Performance is the result obtained by an organization that is both profit-oriented and non-oriented which is produced during a period time [12]. The results of the work obtained are under the objectives of the organization, namely the quality of work, quantity of work, and efficiency. Performance is also the ability and attitude of employees in completing their duties and responsibilities at work that can be seen from 3 indicators, namely quality, quantity, and presence[13][14].

\subsection{Job satisfaction}

Job satisfaction is a positive feeling about work that results from an evaluation of its characteristics[15]. Job satisfaction is a driving factor in increasing employee performance which in turn will contribute to improving organizational performance[16]

\subsection{Leadership}

Leadership is an activity or art that influences other people to work together based on the person's ability to guide others in achieving the desired goals of the group[17]. Leadership is the process of influencing an individual towards another person to achieve a common goal as the use of power and influence to direct followers' activities towards achieving goals[18]

\subsection{Path Analysis}

Path analysis is an extension of multiple linear analyses[19]. Path analysis techniques are used to analyze causal 
relationships inherent in variables. This analysis is arranged in a temporary sequence using the path coefficient as the amount of value in determining the magnitude of the influence of exogenous independent variables on the endogenous dependent variable[20].

\subsection{Data Sampling}

This research is an associative study aimed at knowing the relationship between two or more variables. The primary data in this study were the results of the questionnaire related to the variables studied as many as 113 respondents from employees of PT. FIF Rantauprapat. The path analysis technique is used to test the relationships between variables with the help of SPSS and AMOS software version 18. The thinking framework in this study is shown in Figure 1.

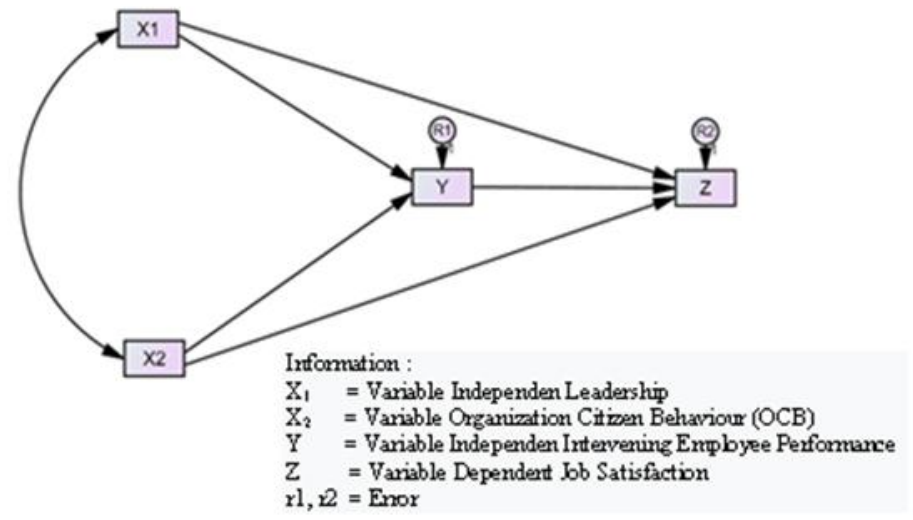

Fig. 1. Framework

\section{RESULT AND DISCUSSION}

The value of the relationship between data constructs is seen based on the probability value ( $p$-value) with the basis of the decision if the value of $\mathrm{P}>0.05$ then $\mathrm{H} 0$ is accepted and if the value of $\mathrm{P}<0.05$ then $\mathrm{H} 0$ is rejected. Figure 2 shows the path coefficients listed are not standardized so that comparing between coefficients with one another is used standardized coefficient.

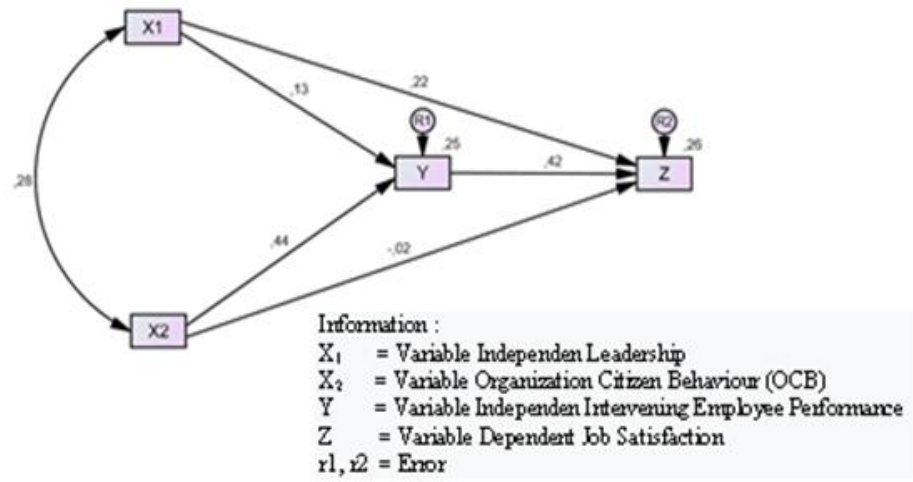

Fig.2 Output Path Analysis with AMOS

Based on the test results, the coefficient of the renewable path can be seen in table 1 .

Table 1 Regresian Weight

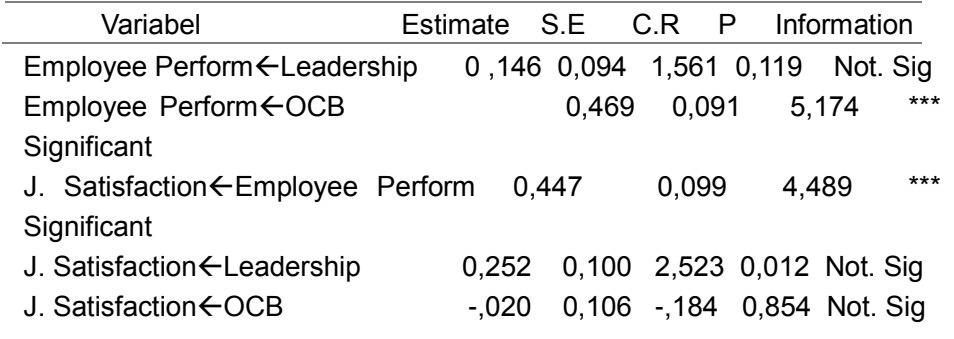

\section{Conclusions}

The test results show leadership does not have a significant direct relationship to employee performance through job satisfaction variables because it has a p-value (0.119) greater than the level of sig $(0.1)$ and has $t$-value $(1,561)$ smaller than t- hit (1.96). Whereas OCB has a significant direct relationship to job satisfaction through employee performance variables because it has a p-value $(0,000)$ smaller than the value of the sig level $(0,1)$ and has $t$-value $(5,714)$ greater than $t$ hit $(1,96)$, although indirectly has a non-significant relationship to job satisfaction on employee performance variables because it has a p-value (0.854) greater than the value of the sig level (0.1) and has a smaller $t$-value (-0.854) even negative from $t$ hit (1.96).

Leadership indirectly has a significant relationship to job satisfaction through employee performance variables because it has a p-value $(0,000)$ smaller than the value of sig $(0.1)$ and has $t$-value $(2,523)$ greater than $t$-hit $(1,96)$. For job satisfaction has a direct and significant relationship to job satisfaction because it has a p-value $(0,000)$ greater than the value of the sig level $(0,1)$ and has $t$-value $(4,489)$ smaller than $t$ hit $(1,96)$.

\section{REFERENCES}

[1] Dewi Lina, "ANALISIS PENGARUH KEPEMIMPINAN DAN BUDAYA ORGANISASI TERHADAP KINERJA PEGAWAI DENGAN SISTEM REWARD SEBAGAI VARIABEL MODERATING," J. Ris. Akunt. dan Bisnis, vol. 14, no. 1, pp. 7797, 2014

[2] Dede Kurnia Ilahi, M. D. Mukzam, and A. Prasetya, "PENGARUH KEPUASAN KERJA TERHADAP DISIPLIN KERJA DAN KOMITMEN ORGANISASIONAL," J. Adm. Bisnis, vol. 44, no. 1, 2017.

Adisty Herwidaningtyas Soeyitno, "Relationship between Employee Perceptions of Supervisor Participative Leadership Styles to Performance in the Muji Rahayu Hospital Employees Surabaya," J. Psikol. Ind. dan Organ., vol. 2, no. 1, 2013.

[4] Darmawan, Irfan, and Maisaroh, "Pengaruh Kepemimpinan Transformasional Dan Kepuasan Kerja Terhadap Organizational Citizenship Behavior Pada Islamic Boarding School Tingkat Sma Di Yogyakarta," J. Apl. BISNIS, vol. 17, no. 2, 2017.

Vadeveloo Thenmolli, N. S. Ngah, and Kamaruzaman Jusoff, "The Effect of Leadership Behavior Among Academician of University Teknologi MARA Terengganu," Manag. Sci. Eng., vol. 3, pp. 1-8, 2009.

[6] Balthazard Pierre A, David A. Waldman, and John E. Warren, "Predictors of the Emergence of Transformation Leadership in 
Virtual Decision Team," Leadersh. Q., vol. 20, 2009.

[7] Debora Eflina Purba and A. N. L. Seniati, "PENGARUH KEPRIBADIAN DAN KOMITMEN ORGANISASI TERHADAP ORGANIZATIONAL CITIZENZHIP BEHAVIOR," MAKARA Sos. Hum., vol. 8, no. 3, pp. 105-111, 2004.

[8] Arief Adhy Kurniawan, "Status Karyawan Sebagai Variabel Moderasi Antara Motivasi Dan Komitmen Organisasi Terhadap Organizational Citizenship Behaviour," J. BISNIS DAN Manaj., vol. 3, no. 2, pp. 92-106, 2015.

[9] P. M. Podsakoff, S. B. MacKenzie, J. b Paine, and D. G. Bachrach, "Organizational Citizenship Behavior: A Critical Review of the Theoretical and Empirical Literature and Suggestions for Future Research," J. Manage., vol. 26, pp. 513-563, 2007.

[10] L. K. Ticoalu, "Organizational Citizenship Behavior (OCB) dan Komitmen Organisasi Pengaruhnya Terhadap Kinerja Karyawan," J. Ekon. Manaj. Bisnis dan Akunt., vol. 1, no. 4, pp. 782-790, 2014.

[11] Triana Fitriastuti, "PENGARUH KECERDASAN EMOSIONAL, KOMITMEN ORGANISASIONAL DAN ORGANIZATIONAL CITIZENSHIP BEHAVIOR TERHADAP KINERJA KARYAWAN," J. Din. Manaj., vol. 4, no. 2, pp. 103-114, 2013.

[12] F. Irfan, Manajemen Kinerja. Bandung: Alfa Beta, 2011.

[13] RULI ALIFIA NOVIANTI, “PENGARUH STRES KERJA TERHADAP MOTIVASI KERJA DAN DAMPAKNYA TERHADAP KINERJA KARYAWAN DI BAGIAN FUNDING OFFICER DAN ACCOUNTING OFFICER PT. BANK RAKYAT INDONESIA (PERSERO), TBK. CABANG BANGKALAN, MADURA.," J. Ilmu Manaj., vol. 4, no. 4, 2016.

[14] F. Sanjaya, "Pengaruh Stres Kerja Terhadap Kinerja Karyawan Dengan Kecerdasan Emosi Sebagai Moderating Variabel," J. Econ. Educ., vol. 1, no. 2, 2012.

[15] Masrukhin and Waridin, "Pengaruh Motivasi Kerja, Kepuasan Kerja, Budaya Organisasi dan Kepemimpinan terhadap Kinerja Pegawai.," J. Ekon. Bisnis, vol. 7, no. 2, 2012.

[16] A. A. N. B. Dhermawan, I. G. A. Sudibya, and I. W. M. Utama, "PENGARUH MOTIVASI, LINGKUNGAN KERJA, KOMPETENSI, DAN KOMPENSASI TERHADAP KEPUASAN KERJA DAN KINERJA PEGAWAI DI LINGKUNGAN KANTOR DINAS PEKERJAAN UMUM PROVINSI BALI," Manajemen, Strateg. Bisnis, dan Kewirausahaan, vol. 6, no. 2, pp. 173-184, 2012.

[17] K. Kartono, Pemimpin dan Kepemimpinan. Jakarta: PT. Rajawali Grafindo Persada., 2011.

[18] R. Kreitner and Angelo Kinicki, Organizational Behaviour, Eight Edition, 8th ed. New York: McGraw-Hill/Irwin, 2008.

[19] D. Streiner L, "Finding Our Way: An Introduction to Path Analysis," Canada J. Psychiatry, vol. 50, no. 2, 2005.

[20] Jonathan Sarwono, Path Analysis. Jakarta: Elex Media Komputindo, 2014. 